\title{
HENRY JOHN PERCY OAKLEY
}

OAKLEX, who died suddenly on 3 February 1942, was born on 22 September 1878 , well within the sound of Bow Bells. He was proud of being a true Cockney and loved London as only a Cockney can. It was fit and proper that he should have worked within the old city walls, that he should have been a freeman of the city, and that he should have fought with and commanded London Regiments.

After leaving Birkbeck School, Oakley joined the staff of the North British and Mercantile Insurance Company and remained there for the rest of his life, having been Actuary and Life Manager for some years before his death. He became a Fellow of our Institute in 1905 and soon after was a tutor for the old Part III examination in Hampson's classes. He was on the Council of the Institute more or less continuously from 192 I, filled various offices including the Chairmanship of the Students' Society and was elected President in 1939. On the insurance side he had been Chairman of the Life Offices' Association and of the Insurance Officials' Society.

Oakley's written contributions began in 1908 with a short note on Lidstone's $Z$ method of valuing endowment assurances, and except for this, for his presidential address, for a light-hearted paper on life assurance (f.C.I.I. Vol. XxxIV, p. II), and for his recent tribute to Willie Robertson, all his contributions to actuarial and insurance journals that $I$ have traced related to annuity business, mortality investigations, and the tables required for practical use. The first paper was in 1909 and dealt with the valuation of annuities, the rates that should be charged, and many practical points. It was probably due to this contribution that he was put on the Committee that investigated the mortality of annuitants for 1900-20 on behalf of the Institute and Faculty, and when that work was finished the Institute made him a member of the Committee responsible for the continuous investigation of the mortality of lives assured and annuitants. He took over the supervision of the work, looked after the men tabulating the results or calculating the tables, and did far more than his share of troublesome hack-work until some years later when Smither relieved him of most of the details. Oakley was keenly interested in the work, and either alone, or jointly with others, published much in comnexion with it. He was a generous and indefatigable collaborator, always willing to lift the burden from other people's shoulders and sympathetic with others' views. When work is shared by two or more people and there is real collaboration, it is impossible to allocate the contribution of each, but I may recall that when we were first discussing the forecast of mortality of annuitants Oakley was insistent that the form adopted must be such that the resulting monetary tables could be used easily. This led to the idea of 


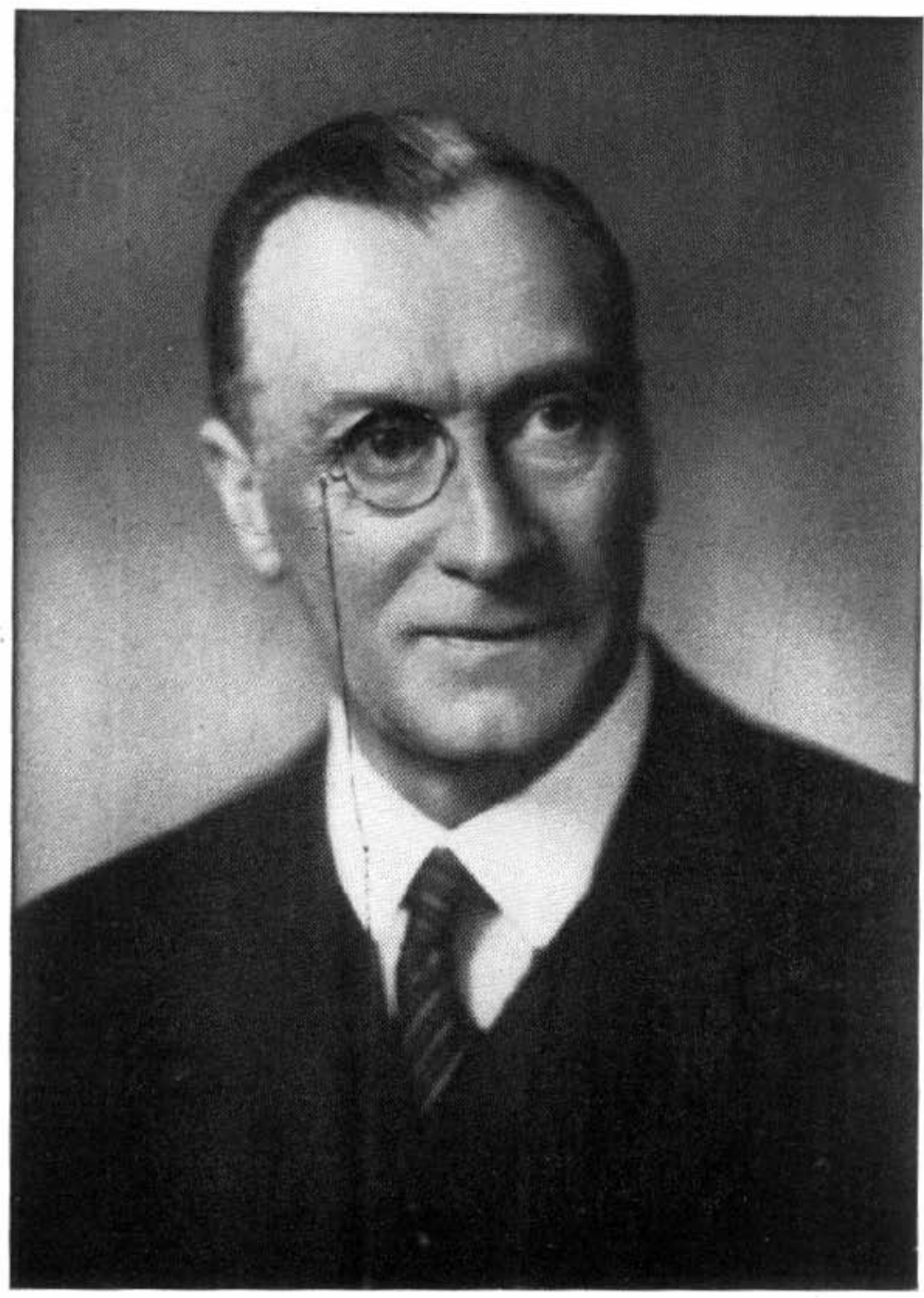

Henry Fohn Percy Oakley 
setting out the forecast in the manner actually adopted, and we then had to see whether the resulting form implied assumptions that could be justified; much of the explanation given was in Oakley's own words. $\mathrm{He}$ was also anxious to restrict the size and number of books that would have to be used in practical office work, and I well remember his pleasure when he found that both last-survivor and joint-life annuities could be compressed into about a hundred pages. Later on it was even more difficult to get the monetary tables for assurances into a single volume of moderate dimensions, and many of the devices adopted arose from his ingenious suggestions.

One of the most important tasks that fell to Oakley's lot during his Presidency was to go to Canada and the United States as head of the delegation of British actuaries in September 1938. He had never been in America before, but from the moment he set foot on the other side everything he did won the admiration of his British colleagues and the affection of their hosts. Oakley paid another visit to America to attend the jubilee celebration of the Actuarial Society and to make a presentation on behalf of the Institute; his own enjoyment of the two visits is indicated by his account of them at the annual meeting of the Institute, while the appreciation on the other side was shown by his election as an Honorary Fellow of the Actuarial Society and a Fellow of the American Institute of Actuaries.

Oakley would never have regarded himself as a profound theoretical actuary or a brilliant business man; he considered himself a "simple fellow' and an 'ordinary man'. To some extent his estimate of himself was correct, although it is far from 'ordinary' to reach the top of one profession and do very well in another or to possess Oakley's capacity for work, his quickness, energy and enthusiasm, while his common sense was more valuable to the North British than actuarial profundity or those less stable qualities that masquerade as brilliance.

Outside his actuarial and insurance work, Oakley showed the greatest interest in military affairs. He had become a Territorial Officer before the war of $19 \mathrm{I}_{4}-\mathrm{I} 8$; he was mobilized with the City of London Brigade R.F.A. and served in France from I9I5 to I9I9. He was Staff Captain in 1918-19 to the 4oth Division R.A., received the Military Cross and was mentioned in despatches. After the war he retained his interest in the Territorials and commanded the 9oth (City of London) Field Brigade R.A. (T.A.) from 1927 to 1933 . He was Honorary Colonel of the Brigade jointly with the Lord Mayor after 1938 , and, at the time of his death, he was Military Member of the Council and Chairman of the Finance Committee of the City of London Territorial Army Association. Oakley showed how much this military work counted with him by references to it and especially to gunnery in speeches at the Institute or Faculty or in those after-dinner speeches at the Actuarial Clubs which must be fresh in many of our memories. He showed it in other 
ways, such as by studying and making a very good collection of military medals; he came to be regarded as an authority, and has helped the Red Cross, during the present war, with advice as to the sale of medals for that charity. Those who were in Quebec with him will remember his description, on the spot, of the capture of the Heights of Abraham, and a smaller number of us will recollect his equally enthralling talk about Waterloo when we went there after attending a meeting in Brussels on International Congress business.

In addition to all this, Oakley was on the governing bodies of the City of London College and of four hospitals, including St Bartholomew's, and found time to take a keen interest in Boys' Clubs; it was when attending a meeting of the Essex Federation of Boys' Clubs that he died so suddenly and unexpectedly.

Oakley had the endearing magic of a Dickensian character; there was indeed something about his family life with its happy simplicity and background of religion, something about the family itself, his wife, his invalid daughter, his son (so like himself), and something about his own way of thinking of others without being long-faced and serious, that showed that the kindliest characters that Dickens described are still true to life. Perhaps it may all be summed up by saying that Oakley took the happiness and success in life with a boy's joy, the disappointments and sorrows with a brave smile, and that he gave to others-surely the best thing to give-friendship.

W, P, E. 